\title{
LIFE CYCLE ASSESSMENT OF SECONDARY EXTRUDED ALUMINUM PRODUCTION PROCESS IN INDUSTRIAL CITY OF ARAK
}

\author{
ZARE, R. ${ }^{1,4}-$ NOURI, J. ${ }^{1 *}-$ ABDOLI, M. A. ${ }^{2}-$ ATABI, F. ${ }^{3}$ \\ ${ }^{I}$ Department of Environmental Management, Graduate School of Environment and Energy, \\ Science and Research Branch, Islamic Azad University, Tehran, Iran \\ ${ }^{2}$ Faculty of Environment, University of Tehran, Tehran, Iran \\ (phone: +98-912-371-6971; fax: +98-912-371-6971; email: mabdoli@ut.ac.ir) \\ ${ }^{3}$ Department of Environmental Engineering, Graduate School of Environment and Energy, \\ Science and Research Branch, Islamic Azad University, Tehran, Iran \\ (phone: +98-214-486-1681; fax:+98-214-486-1681; email: far-atabi@jamejam.net) \\ phone: +98-918-361-8297; fax: +98-863-221-4154;email: r.zare@srbiau.ac.ir \\ *Corresponding Author: \\ e-mail: nourijafar@gmail.com \\ (phone: +98-912-115-8827; fax: +98-912-115-8827) \\ (Received $9^{\text {th }}$ Aug 2015; accepted 21 $1^{\text {st }}$ Jan 2016)
}

\begin{abstract}
In this study, the life cycle assessment model for the secondary extruded aluminum represents a cradle-to-gate process that starts with recycling aluminum scrap and ends in the ultimate product of extruded aluminum transferred to final product manufacturer. In the following, data are mainly collected from the literature, and ecoinvent3's database. The quantitative analysis of the use of the energy and pollutants for production of the secondary extruded aluminum are estimated with eco-indicator-99 methodology and SimaPro8.0.4 package. The impact of the secondary extruded aluminum production on the environment is studied by evaluating three damage impacts: human health, ecosystem quality and resources. Results indicate that the resources make the highest contribution by $0.58 \mathrm{pt}(4284.35 \mathrm{MJ})$ and human health by $0.16 \mathrm{pt}(0.00136 \mathrm{DALY})$ is located in the next rank. The endpoint ecosystem quality (44.64 $\mathrm{PDF} * \mathrm{~m}^{2} \mathrm{yr}$ ) is insignificant in this process. Also, the total required energy for manufacturing of $600 \mathrm{~kg}$ aluminum profile in the model was $8842 \mathrm{MJ}$. Based on the results, the impact of the secondary aluminum extrusion process on the ozone layer depletion is shown to be insignificant. Also, despite using aluminum scraps, the model incurs significant environmental load. The study is implemented in the industrial city of Arak.
\end{abstract}

Keyword: environment, secondary aluminum, scrap, LCA

\section{Introduction}

Since it has been predicted that the aluminum industry is going to be shifted to developing countries (Menzie, 2010; Sevigné-Itoiz et al., 2014), this study is implemented in Iran which is a developing country. Primary aluminum production is one of the most energy-intensive processes in the metals (Ferreira et al., 2014). Meanwhile, compared with other materials, metals have the greatest potential for methodical recycling (Paraskevas et al., 2015). The results of numerous studies have suggested that the emissions and the use of the energy in aluminum production were reduced in the secondary aluminum compared to the primary aluminum (Atherton, 2007; Blomberg and Söderholm, 2009; Ferreira et al., 2014; Green, 2007; Hatayama et al., 2009; Shkolnikov et al., 2011). The environmental credits are a result of reduction in 
raw materials, energy and emissions related to the materials recycling process (Ferreira et al., 2014; Lacarrière et al., 2015). For example, aluminum scrap may be recycled straightly by hot extrusion that needed nearly $10 \%$ of energy demand for recycling by re-melt process (Ingarao et al., 2011). Extruded aluminum is widespread used for building sectors.

The secondary aluminum scrap can be categorized as old scrap that is generated following the end-of-life of products, or new scrap that will be created through the casting, semi-finished (such as extruded aluminum profile) and manufacturing production. Hence, new and old scrap (wastes) are converted into the secondary aluminum (Green, 2007). In this case, primary and secondary aluminum may exchange each other into each of extruded aluminum production. Really, it is impossible to determine whether a product is made from bauxite as raw material or from secondary aluminum as recycled material (Frees, 2008). Recycling aluminum from scrap consumes approximately twenty times less energy than the primary aluminum production (Liu and Müller, 2012). The increment in new scrap generation could be related to the increase of semi-finished and final products, as losses throughout their incurred production are classified as new scrap and represented into the production path. The growth in old scrap generation is related to improvements in waste management as a consequence of the presentation of the Packaging waste directive and the end-of-life vehicle directive (Sevigné-Itoiz et al., 2014).

LCA is a principled method that titles the environmental impacts throughout a product's life cycle from raw material acquisition through production, use, end of life treatment, recycling and final disposal (Bertram et al., 2009). A complete LCA study includes four stages: goal and scope definition; life cycle inventory; environmental impact assessment and, finally, interpretation (Chang et al., 2014). The reported LCA in international standard ISO 14040-2006 (ISO, 2006a) and ISO 14044-2006 (ISO, 2006b) may be applied to the environmental aspects. Various studies on aluminum LCA have been done (Detzel and Mönckert, 2009; Ding et al., 2012; Gao et al., 2009; Gatti et al, 2008). Among the aluminum LCA, usual, primary aluminum analysis is used for analyzing the environmental negative effects of products (Liu and Müller, 2012), although some LCA' studies have been done on aluminum alloys, semifabricated or finished aluminum products (Detzel and Mönckert, 2009; Hong et al., 2012; Paraskevas et al., 2015; Sevigné-Itoiz et al., 2014). For example, based on LCA model, with the actual situation of aluminum industry in China in 2008, an analysis of the use of energy and pollutants related to aluminum alloy extrusion were carried out (Ding et al., 2012). In what follows, the LCA model is implemented on extruded aluminum. On the other hand, most LCA' studies in aluminum industries don't complete and limit only on a particular process (Liu and Müller, 2012; Norgate and Haque, 2010; Olivieri et al., 2006; Tan and Khoo, 2005). It may be run via grave to gate or gate to gate approach. In addition, it can be semi- finished products. SimaPro software package to be extensively used by scholars to perform LCAs studies (Ferreira et al., 2014). In present study, the LCA model is a cradle-to-gate procedure. The system boundaries determines the unit processes to be contained in the system (Ferreira et al., 2014). In this study, the system boundary of secondary extruded aluminum as a unit process starts with recycling aluminum scrap and ends in the ultimate product of extruded aluminum transferred to final product manufacturer. Once produced, aluminum ingots can undergo numerous fabrication processes, 
normally rolling, extrusion, and casting, to be transformed into different semi-finished products, for example sheet, foil, and profile (Liu and Müller, 2012).

Carbon dioxide emissions increased in the world, more than 2.7 percent over 2011. Meanwhile, the industry plays an important role in a way that almost 40 percent of total energy consumption related to the industrial activities (Ingarao et al., 2011). In extruded aluminum the emission factor, $\mathrm{CO} 2-\mathrm{eq} / \mathrm{kg}$, is about $0.34 \mathrm{~kg}$ (Choate and Green, 2003). Also, the published energy quantities of U.S. aluminum rollers and extruders, indicate a broad limit from 2.8 $\mathrm{MJ} \mathrm{kg}^{-1}$ to $43.2 \mathrm{MJ} \mathrm{kg}^{-1}$ (Liu and Müller, 2012). Moreover, it is possible to extrude products without the necessity of additional heat treatments and without dissipation of material. The minimum theoretical energy to extrude a product, in this case, is made of only two components: the energy required preheating the billet to extrusion temperature and the energy required to alter forming the material via a change forming.

Based on the outcomes of a study, the minimum energy intensity is equal to 0.44 $\mathrm{kWh} / \mathrm{kg}$ of the secondary aluminum, when results are assumed to be $50 \%$ for heating and $75 \%$ for the hydraulic and electric system (Green, 2007). Considering the fact that no case studies related to the LCA of extruded aluminum have already been done in the Islamic Republic of Iran; a life cycle assessment model is developed using SimaPro8.0.4 tool to calculate emissions from the production of the secondary extruded aluminum in this country in 2015.

\section{Material and methods}

\section{Case study}

A case study on aluminum industries in Arak, the industrial area center of the Islamic Republic of Iran, is presented. The unit process includes materials, energy, and environmental releases associated with the secondary aluminum extruding operations. The study is really a cradle-to-gate LCA, thus it ends in the manufactory gate, with the final product of extruded aluminum accessible to transport. The initial material for the secondary extruded aluminum is billet and the result of the process is finished extruded profiles transferred to final product manufacturer. Life cycle inventory (LCI) results are introduced in various impact categories according to characterization factors. The life cycle impact assessment (LCIA) of the secondary extruded aluminum on the environment is studied by evaluating three damage impacts and eleven impact categories. The eco-indicator 99 impact assessment methodology is applied in SimaPro8.0.4 education package.

\section{Secondary extruded aluminum}

Extrusion is the procedure of forcing a metal ingot or billet via a steel die to create a stretched shape of consistent cross section. Extruded products include bars, rods, and defined products called shapes or profiles. Extrusion is significant because aluminum can be readily extruded; this process is difficult for other metals. Extrusion products are more and more used as structural and body components. The secondary aluminum metal is commonly cast into large ingots. The starting material for the secondary extrude aluminum is billet, i.e. a several meters rod in a size $20-50 \mathrm{~cm}$. These billets are mainly produced by direct current casting technology. The ends of the billets are usually sawed at the cast plant for re-melting. The billet may be cut into smaller rod pieces before the 
extrusion process. Before extrusion, the billet is preheated usually to 450 and $500{ }^{\circ} \mathrm{C}$. The billet is then sheared, or cut into length, and deposited right into a hydraulic press. The straightened lengths are cut into finish length multiples and put into an aging furnace to accomplish an ideal operation of tempering. Lengths are then drilled and shaped and placed into a covering process. There are over 40 extrusion plants in Arak. Finally, fabricated extruded profiles transferred to final product plants. The extrusion from cast billet around fabricated profile generates about $320 \mathrm{~kg}$ of scrap of $600 \mathrm{~kg}$ of extrusion. These scraps are recycled into new ingot through re-melting that is completed either on-plant in integrated cast houses or externally.

\section{Results}

\section{The goal and scope}

In this study, the LCA model for secondary extruded aluminum represents a cradleto-gate procedure, beginning at recycling aluminum scrap and ending in the finished product of extrude aluminum that transferred to product plants. The presented model for $600 \mathrm{~kg}$ of the secondary extruded aluminum is implemented in Arak.

\section{Life cycle Inventory}

Table 1 shows the main material related to environmental impacts of the secondary extruded aluminum. In Table 1, the inventories are reported for the secondary extruded aluminum production. The key data were utilized in the SimaPro8.0.4 model. Table 1 demonstrates that the air emissions from the production of 600 kilogram of the secondary extruded aluminum were $\mathrm{CO}_{2}(1754000 \mathrm{~g}), \mathrm{SO}_{2}(8990 \mathrm{~g})$ and $\mathrm{N}_{2} \mathrm{O}(2690 \mathrm{~g})$. The emissions to water were Chloride $(43860 \mathrm{~g})$, lithium $(1220 \mathrm{~g})$, bromide $(200 \mathrm{~g})$ and suspended solids (53330 g).Also, this data indicates that the usage of energy resources would be to a considerable extent comprised of electricity $(4580 \mathrm{MJ})$ and natural gas (3440 MJ).

Table 1. Inputs and outputs for the secondary extrude aluminum production

\begin{tabular}{|c|c|c|c|c|c|}
\hline Inputs & Unit & Total & Outputs & Unit & Total \\
\hline Raw materials & & & Air emissions & & \\
\hline Aluminum scraps & $\mathrm{kg}$ & 595 & Particulates, $<2.5$ um & $\mathrm{kg}$ & 0.09 \\
\hline Natural gas & $\mathrm{M}^{3}$ & 286 & Particulates, > 10 um & $\mathrm{kg}$ & 0.08 \\
\hline Electricity & MJ & 4580 & BTEX $^{1}$ & $\mathrm{~kg}$ & 0.07 \\
\hline Water & $\mathrm{M}^{3}$ & 1.14 & Hydrogen chloride & $\mathrm{kg}$ & 0.007 \\
\hline Outputs & & & Water emissions & & \\
\hline Air emissions & & & $\mathrm{BOD}_{5}{ }^{3}$ & $\mathrm{~kg}$ & 0.63 \\
\hline Carbon dioxide, fossi ${ }^{1}$ & $\mathrm{~kg}$ & 1754 & $\mathrm{COD}^{4}$ & $\mathrm{~kg}$ & 0.84 \\
\hline Sulfur dioxide & $\mathrm{kg}$ & 8.99 & Suspended solids & $\mathrm{kg}$ & 53.33 \\
\hline Nitrogen oxides & $\mathrm{kg}$ & 2.69 & Chloride & $\mathrm{kg}$ & 43.86 \\
\hline $\mathrm{NMVOC}^{2}$ & $\mathrm{~kg}$ & 0.58 & Magnesium & $\mathrm{kg}$ & 1.35 \\
\hline VOC, volatile organic compounds & $\mathrm{kg}$ & 0.20 & Lithium & $\mathrm{kg}$ & 1.22 \\
\hline Particulates, $>2.5 \mathrm{um}$, and $<10 \mathrm{um}$ & $\mathrm{kg}$ & 0.09 & Bromide & $\mathrm{kg}$ & 0.2 \\
\hline
\end{tabular}

${ }^{1}$ Benzene, toluene, ethyl-benzene, and xylene, unspecified ratio, ${ }^{2}$ Non-methane volatile organic compounds, unspecified origin, ${ }^{3}$ Biological Oxygen Demand, ${ }^{4}$ Chemical Oxygen Demand. 
Figure 1 presents a cut from map for $600 \mathrm{~kg}$ of the secondary extruded aluminum (LCA-SimaPro model). Also, Figure 2 shows modeled inventories for 600 kilogram of the secondary extruded aluminum.

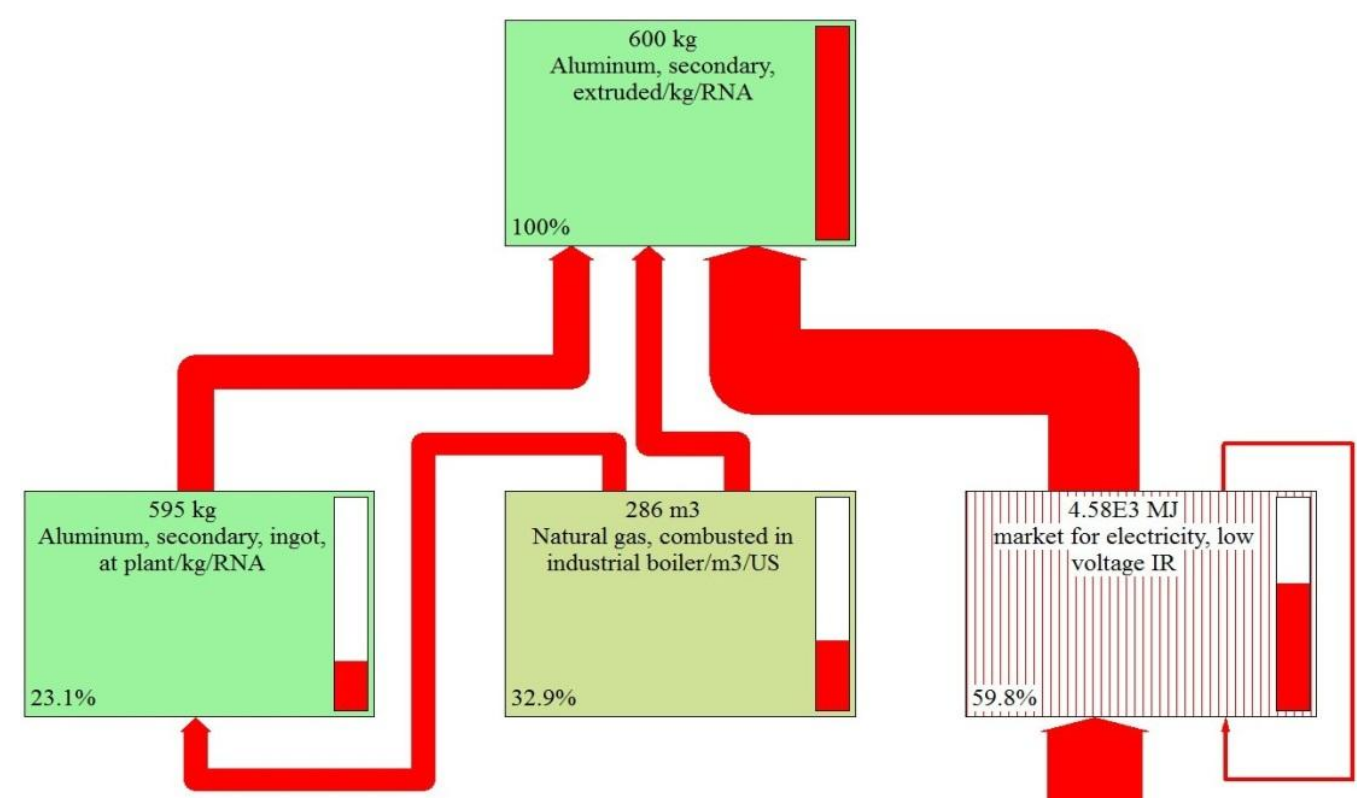

Figure 1. Cut of the map for $600 \mathrm{~kg}$ of the secondary extruded aluminum (LCA-SimaPro).

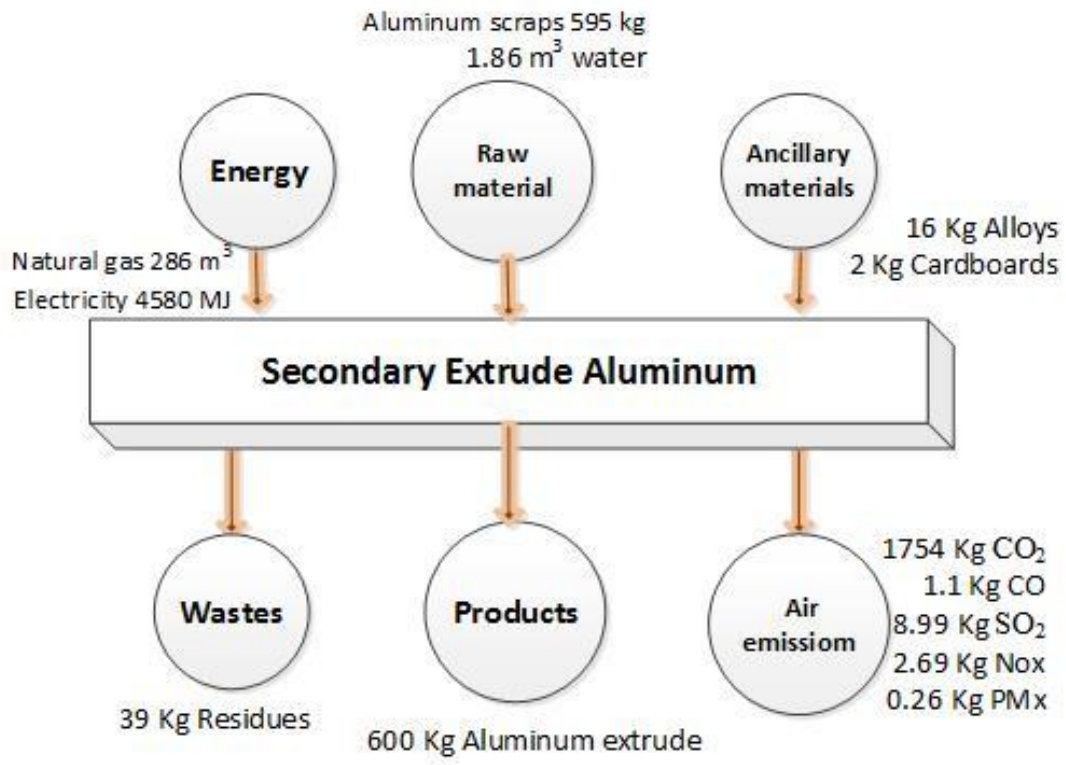

Figure 2. Inputs and outputs for $600 \mathrm{~kg}$ secondary extruded aluminum.

\section{LCIA stage}

In the life cycle impact assessment stage, total inventories, were aggregated into three endpoint categories and eleven impact indicators, according to the eco-indicator 99 method. Endpoint categories are: human health, ecosystem quality and resources. 
Also, midpoint indicators are: carcinogens in DALY (Disability-Adjusted Life Year), respirable organics (DALY), respirable inorganics (DALY), climate change (DALY), radiation (DALY), ozone layer (DALY), eco-toxicity (PDF $* \mathrm{~m}^{2} \mathrm{yr}$ ) (Potentially Disappeared Fraction of species $\times$ square meter $\times$ Year $)$, acidification /eutrophication (PDF * $\mathrm{m}^{2} \mathrm{yr}$ ), land use (PDF * $\mathrm{m}^{2} \mathrm{yr}$ ), minerals (MJ surplus), fossil fuels (MJ surplus)(PRe Consultants, 2013).

Figure 3 present normalized results for environmental impacts of the secondary extruded aluminum, based on damage categories. In Figure 3, it is clear that resources exhibit the greatest contribution, by $0.58 \mathrm{pt}$ (4284.35 MJ surplus) and human health by $0.16 \mathrm{t}(0.00136 \mathrm{DALY})$ is located in next rank. The endpoint ecosystem quality (44.64 $\left.\mathrm{PDF} * \mathrm{~m}^{2} \mathrm{yr}\right)$ is insignificant for this process.

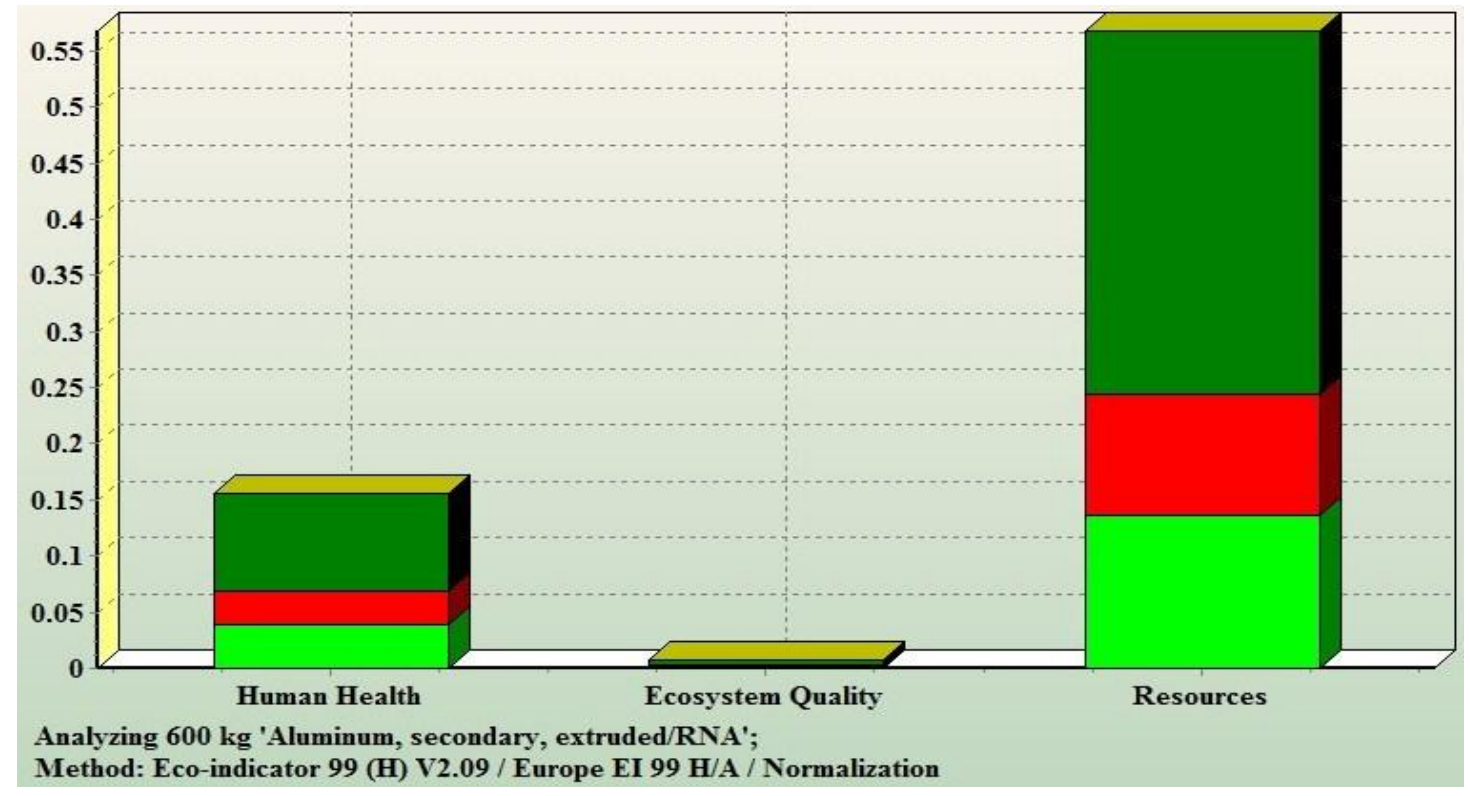

Figure 3. Normalized results for environmental impacts for the production of $600 \mathrm{~kg}$ secondary extruded aluminum, based on endpoint categories.

Figure 4 presents normalized results for environmental impacts of the secondary extruded aluminum. Figure 4, which is based on midpoint indicators, indicates that fossil fuels (4284.35 MJ surplus), respirable inorganic (0.00083 DALY), climate change (0.0004 DALY) and carcinogen (0.00014 DALY) are the most effective indicators.

Figure 5 presents environmental impacts of producing $600 \mathrm{~kg}$ of the secondary extruded aluminum, based on single scores (pt). As it can be seen, natural gas (raw material) with $92 \mathrm{pt}\left(286 \mathrm{~m}^{3}\right)$ is the greatest contributor to environmental impact of 600 $\mathrm{kg}$ of the secondary extruded aluminum. The other raw materials (crude oil $92 \mathrm{pt}-132$ $\mathrm{kg}-822 \mathrm{MJ})$, emissions from air $\left(\mathrm{SO}_{2}\left((0.000491\right.\right.$ DALY $), \mathrm{CO}_{2}(0.000368$ DALY), $\mathrm{NO}_{2}(0.000239$ DALY) and particles (0.00005 DALY)), and finally, emissions from water (arsenic 0.000056 DALY) contribute to a lesser extent.

Figure 6 illustrates environmental impacts of producing $600 \mathrm{~kg}$ of the secondary extruded aluminum, based on human health. Figure 6 shows that the emissions arising from secondary extruded aluminum which show the highest contribution to human health are $\mathrm{SO}_{2}, \mathrm{CO}_{2}$ and $\mathrm{NO}_{2}$ in DALY, respectively. 


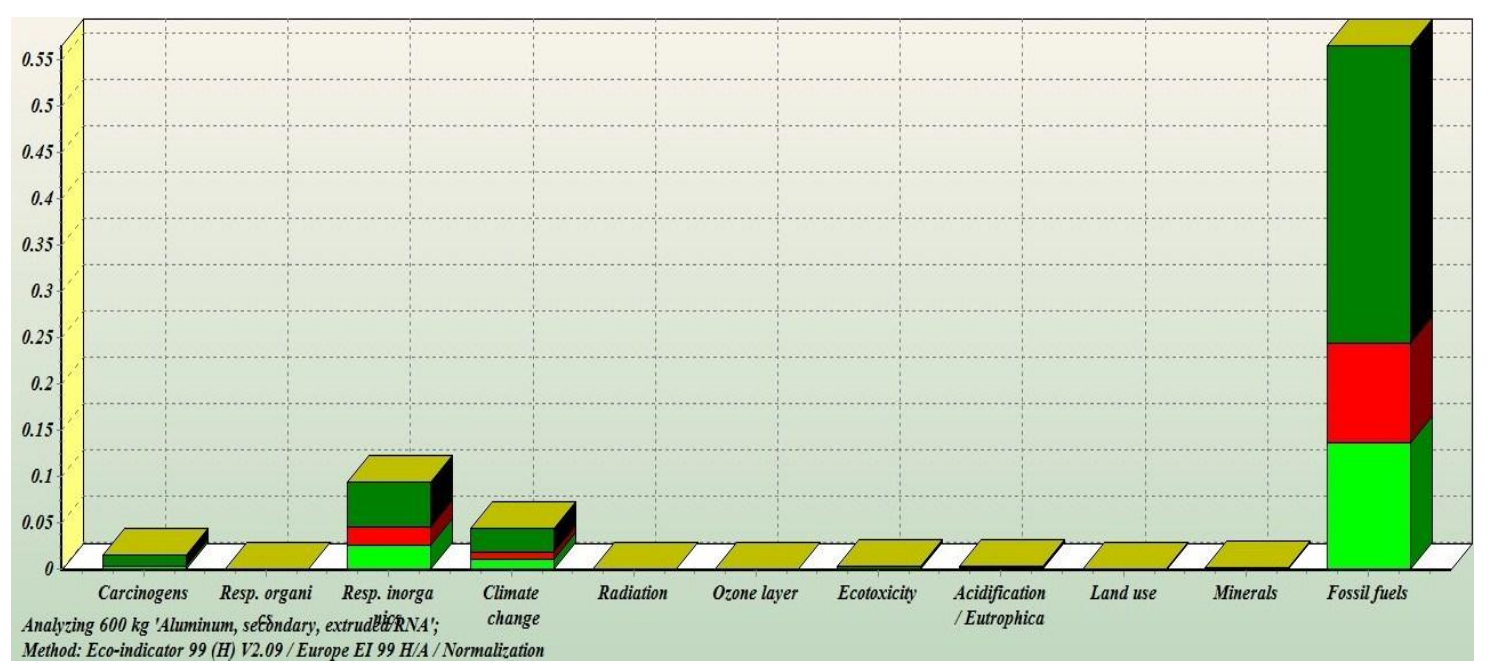

Figure 4. Normalized results for environmental impacts for the production of $600 \mathrm{~kg}$ secondary extruded aluminum, based on midpoint indicators.

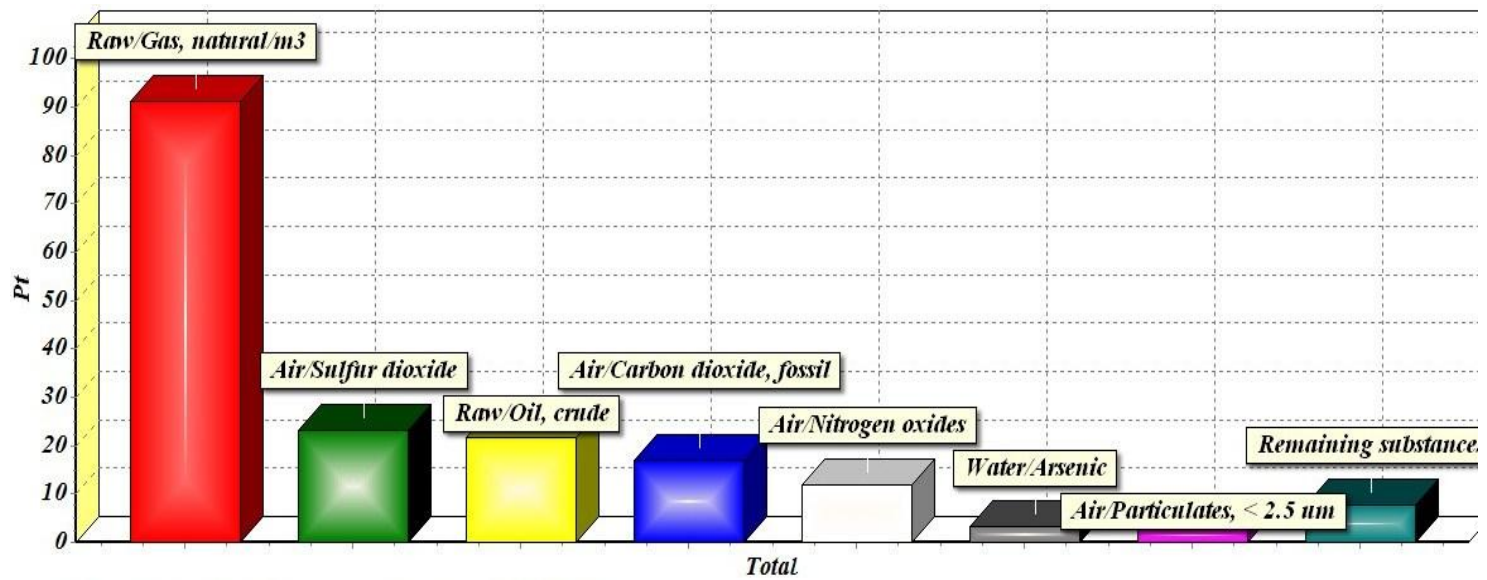

Analyzing $600 \mathrm{~kg}$ 'Aluminum, secondary, extruded/RNA';

Method: Eco-indicator 99 (H) V2.09 / Europe EI 99 H/A / Single score

Figure 5. Environmental impacts for the production of $600 \mathrm{~kg}$ secondary extrude aluminum, based on single scores.

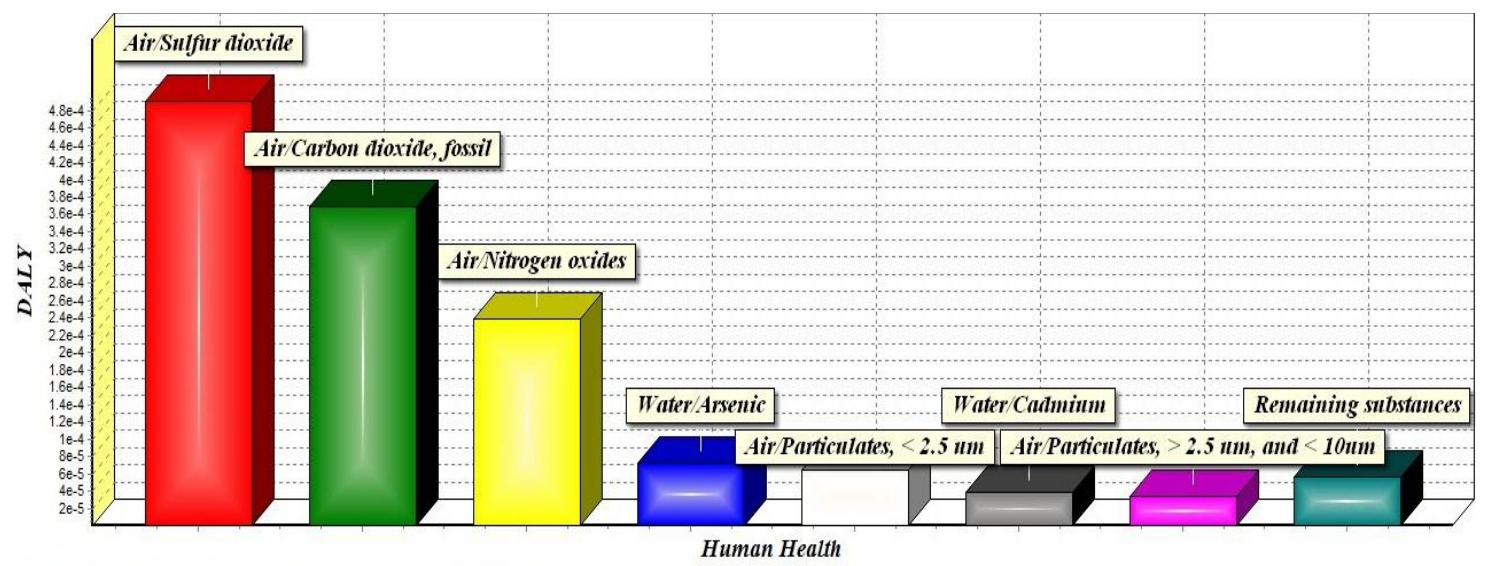

Analyzing $600 \mathrm{~kg}$ 'Aluminum, secondary, extruded/RNA';

Method: Eco-indicator 99 (H) V2.09 / Europe EI 99 H/A / Damage assessment

Figure 6. Environmental impacts for the production of $600 \mathrm{~kg}$ the secondary extrude aluminum, based on endpoint human health. 
Environmental impacts of the production of $600 \mathrm{~kg}$ of the secondary extrude aluminum, based on resp.inorganic are presented in Figure 7. As can be seen, the total resp.inorganic is 0.00083 DALY. Also $\mathrm{SO}_{2}$ and $\mathrm{NO}_{2}$ make up the greatest contributions, with 0.000491 and 0.000239 DALY for $600 \mathrm{~kg}$ of the secondary extruded aluminum, respectively.

Figure 8 presents environmental impacts of the production of $600 \mathrm{~kg}$ secondary extruded aluminum, based on carcinogen. Figure 8 demonstrates, the total carcinogen produced from the secondary extruded aluminum is 0.000138 DALY. Pollutants to water (arsenic 0.00007 DALY, cadmium 0.00004, metallic iron 6.97E-06 in DALY) and pollutants to air (cadmium 0.000012, arsenic 0.000005 in DALY) are the causes of carcinogen due to the secondary extruded aluminum process.

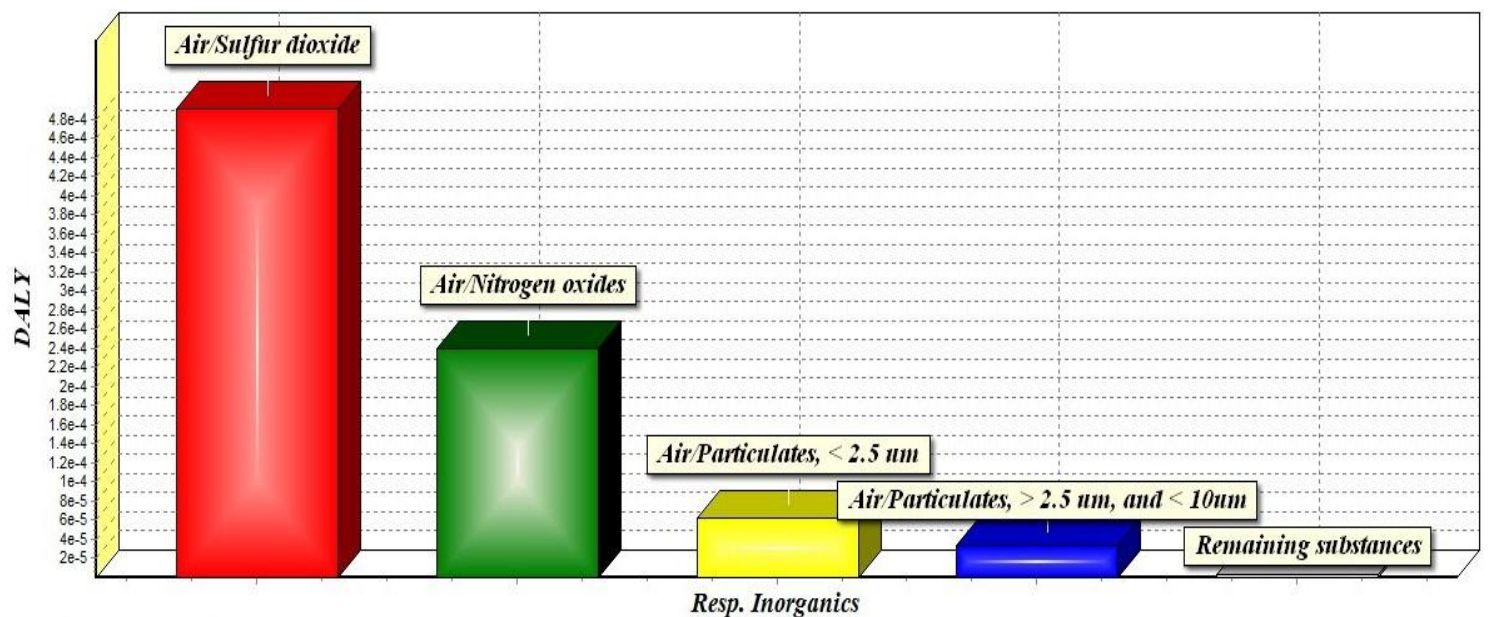

Analyzing $600 \mathrm{~kg}$ 'Aluminum, secondary, extruded/RNA';

Method: Eco-indicator 99 (H) V2.09 / Europe EI 99 H/A / Characterization

Figure 7. Environmental impacts for the production of $600 \mathrm{~kg}$ the secondary extrude aluminum, based on midpoint respirable inorganic.

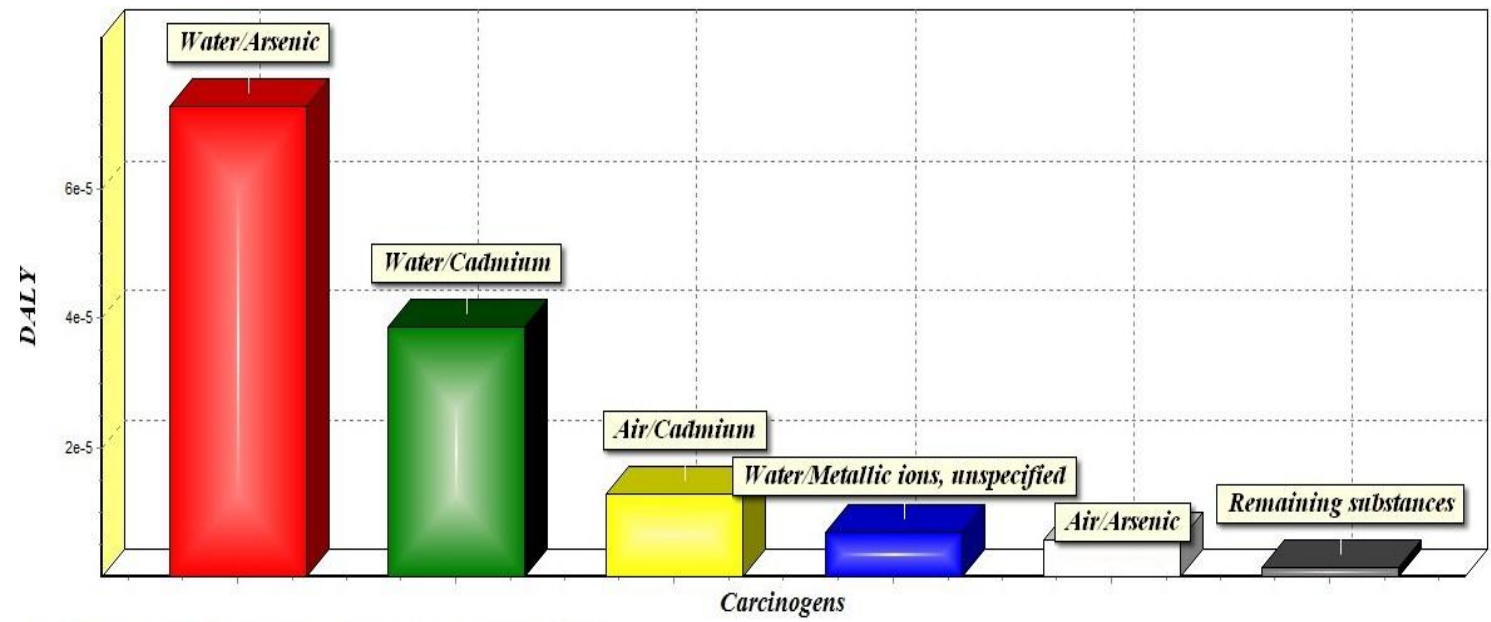

Analyzing $600 \mathrm{~kg}$ 'Aluminum, secondary, extruded/RNA';

Method: Eco-indicator 99 (H) V2.09 / Europe EI 99 H/A / Characterization

Figure 8. Environmental impacts for the production of $600 \mathrm{~kg}$ the secondary extrude aluminum, based on carcinogen midpoint. 


\section{Discussion}

Life cycle assessment was utilized to evaluate the secondary extruded aluminum process. In this study, data were mainly collected from literature, and the eco-invent 3 database. The present LCA was implemented in the industrial city of Arak in 2015. The model for the secondary extruded aluminum represents a cradle-to-gate procedure, beginning at recycling aluminum scrap and ending in the final product of aluminum extrusion.

The basic objective of the impact assessment stage would be to transform the long list of life cycle inventory output straight into a limited number of indicators. These indicators will show the impact of each operation on the environment. One evaluation was based on endpoint indicators and midpoint indicators. Endpoint indicators tend to be more uncertain and midpoint indicators are apt to have a shorter perspective. In this study, 11 impact categories were applied with average weighting and normalization based on European standards. To accomplish this, the eco-indicator 99 method is used. This method converts the long inventory of outputs in set of indicators which receive the severity to each impact category based on some weighting.

As was seen previously, the usage of aluminum scrap incurs an environmental credit. In spite of this, it is evident that the energy consumption is the highest contributor to negative environmental impacts of production of 600 kilogram of the secondary extruded aluminum. The resources endpoint to the secondary extruded aluminum model accounts for nearly $67 \%$ and is the environmental problem area for this product system. Hence, one of the most results read from present research is that natural gas consumption is most responsible for the environmental impacts in this process.

The human health $(\mathrm{HH})$ indicator estimates the negative consequences of a defined process on humans. The total $\mathrm{HH}$ from the secondary extruded aluminum production was 0.000138 in DALY. In this case, respirable inorganic, climate change and carcinogen had the greatest share in this category. As was shown, for respirable inorganic, the sulfur dioxide and nitrogen oxides (both emissions to air) resulted from the secondary extrude aluminum model had the highest negative impact on humans. In case of climate change, carbon dioxide with 0.00368 DALY was a large contributor and, in fact, the main contributor to the negative environmental consequences of the secondary extruded aluminum process.

The carcinogens are calculated in DALY. It can be seen that the arsenic and cadmium with 0.00122 DALY (emissions to water) had the highest impact in this midpoint indicator.

The quality ecosystem aims to outline the negative impact of a certain process on the ecosystem. Based on outcomes of proposed research, quality ecosystem category was insignificant in the secondary extruded aluminum process; it was less than $3.28 \%$ for all system.

Based on results, it could be concluded that the main contributors to the negative environmental impacts of the secondary extruded aluminum were commonly energy supply. We think that the perfect solution would be using new heating technologies to reduce energy requirements through more rapid heating in treatment temperature and using the heat of the casting or finishing forming operation method. The recent method requires less energy. Therefore, the implementation of this method reduces energy requirements in extruding aluminum.

Performing such an analysis based on the assumptions made for the study would have proven useful and provides a base for further works. However, research into this 
issue must also be the subject of future works and further contributions to the growing field of LCA in Iran.

\section{Future work}

- Comparing the potential environmental consequences of different options of the extruded aluminum production with regarding type or origin of raw material and energy resources will be interesting.

- In our opinion, carrying out a cradle-to-gate LCA study in aluminum production process can be interesting and important in industrial city of Arak. A more detailed LCA method would allow aluminum industries to assess environmental burdens of their activities more practical in order to reduce them.

- In addition, extending MCDM methods such AHP, TOPSIS and ELECTRE based on LCA results in aluminum industry can be interesting. This integrated methodology can be used to make the best decision in different methods of primary and secondary aluminum production.

\section{REFERENCES}

[1] Atherton, J. (2007): Declaration by the Metals Industry on Recycling Principles. - The International Journal of Life Cycle Assessment 12(1): 59-60.

[2] Bertram, M., Martchek, K. J., Rombach, G. (2009): Material Flow Analysis in the Aluminum Industry. - Journal of Industrial Ecology 13(5): 650-654.

[3] Blomberg, J., Söderholm, P. (2009): The economics of secondary aluminium supply: An econometric analysis based on European data. - Resources, Conservation and Recycling 53(8): 455-463.

[4] Chang, D., Lee, C. K. M., Chen, C.-H. (2014): Review of life cycle assessment towards sustainable product development. - Journal of Cleaner Production 83: 48-60.

[5] Choate, W. T., Green, J. A. (2003): US energy requirements for aluminum production: historical perspective, theoretical limits and new opportunities: US Department of Energy, Energy Efficiency and Renewable Energy.

[6] Detzel, A., Mönckert, J. (2009): Environmental evaluation of aluminium cans for beverages in the German context. - The International Journal of Life Cycle Assessment 14(1): 70-79.

[7] Ding, N., Gao, F., Wang, Z., Gong, X., Nie, Z. (2012): Environment impact analysis of primary aluminum and recycled aluminum. - Procedia Engineering 27: 465-474.

[8] Ferreira, S., Cabral, M., da Cruz, N. F., Simões, P., Marques, R. C. (2014): Life cycle assessment of a packaging waste recycling system in Portugal. - Waste management 34(9):1725 1735

[9] Frees, N. (2008): Crediting aluminium recycling in LCA by demand or by disposal. - The International Journal of Life Cycle Assessment 13(3): 212-218.

[10] Gao, F., Nie, Z., Wang, Z., Li, H., Gong, X., Zuo, T. (2009): Greenhouse gas emissions and reduction potential of primary aluminum production in China. - Science in China Series E: Technological Sciences 52(8): 2161-2166.

[11] Gatti, J. B., de Castilho Queiroz, G., Garcia, E. E. C. (2008): Recycling of aluminum can in terms of life cycle inventory (LCI). - The International Journal of Life Cycle Assessment 13(3): 219-225.

[12] Green, J. A. (2007): Aluminum recycling and processing for energy conservation and Sustainability. - ASM International, Ohio. 
[13] Hatayama, H., Daigo, I., Matsuno, Y., Adachi, Y. (2009): Assessment of the recycling potential of aluminum in Japan, the United States, Europe and China. - Materials Transactions 50(3): 650-656.

[14] Hong, J., Zhou, J., Hong, J., Xu, X. (2012): Environmental and economic life cycle assessment of aluminum-silicon alloys production: a case study in China. - Journal of Cleaner Production 24: 11-19.

[15] Ingarao, G., Di Lorenzo, R., Micari, F. (2011): Sustainability issues in sheet metal forming processes: an overview. - Journal of Cleaner Production 19(4): 337-347.

[16] ISO, E. (2006a): 14040: 2006. Environmental management-Life cycle assessment principles and framework. - International Standards Organization, Geneva.

[17] ISO, E. (2006b): 14044: 2006. Environmental management-Life cycle assessment requirements and guidelines. - International Standards Organization, Geneva.

[18] Lacarrière, B., Deutz, K. R., Jamali-Zghal, N., Le Corre, O. (2015): Emergy assessment of the benefits of closed-loop recycling accounting for material losses. - Ecological Modelling 315: 77-87.

[19] Liu, G., Müller, D. B. (2012): Addressing sustainability in the aluminum industry: a critical review of life cycle assessments. - Journal of Cleaner Production 35: 108-117.

[20] Menzie, W. (2010): The global flow of aluminum from 2006 through 2025: US Department of the Interior, US Geological Survey.

[21] Norgate, T., Haque, N. (2010): Energy and greenhouse gas impacts of mining and mineral processing operations. - Journal of Cleaner Production 18(3): 266-274.

[22] Olivieri, G., Romani, A., Neri, P. (2006): Environmental and economic analysis of aluminium recycling through life cycle assessment. - International Journal of Sustainable Development \& World Ecology 13(4): 269-276.

[23] Paraskevas, D., Kellens, K., Dewulf, W., Duflou, J. R. (2015): Environmental modelling of aluminium recycling: a Life Cycle Assessment tool for sustainable metal management. - Journal of Cleaner Production 105: 357-370.

[24] PRe Consultants, B. (2013): SimaPro 8 user's manual. The Netherlands.

[25] Sevigné-Itoiz, E., Gasol, C. M., Rieradevall, J., Gabarrell, X. (2014): Environmental consequences of recycling aluminum old scrap in a global market. - Resources, Conservation and Recycling 89: 94-103.

[26] Shkolnikov, E. I., Zhuk, A. Z., Vlaskin, M. S. (2011): Aluminum as energy carrier: Feasibility analysis and current technologies overview. - Renewable and Sustainable Energy Reviews 15(9): 4611-4623.

[27] Tan, R. B. H., Khoo, H. H. (2005): An LCA study of a primary aluminum supply chain. Journal of Cleaner Production 13(6): 607-618.

\section{ELECTRONIC APPENDIX}

Electronic appendix 1: Map for $600 \mathrm{~kg}$ of the secondary extrude aluminum (LCASimaPro) 